\title{
A Rapid Review of the Use of Appropriate Technology in Global Health
}

\author{
Jayoung Park ${ }^{1,2}$, Heesu Shin ${ }^{1,3}$, Hee Joon Choi ${ }^{1}$, Jongho Heo ${ }^{1,4, \dagger}$, Woong-Han Kim ${ }^{1,2,5, \uparrow}$ \\ ${ }^{1}$ Program in Global Surgery and Implementation Science, JW LEE Center for Global Medicine, \\ Seoul National University College of Medicine, Seoul, South Korea \\ ${ }^{2}$ Department of Human Systems Medicine, Seoul National University College of Medicine, Seoul, Republic of Korea \\ ${ }^{3}$ Department of Aerospace Nursing, Aerospace Medical Center, Cheongju, South Korea \\ ${ }^{4}$ National Assembly Futures Institute, Seoul, South Korea \\ ${ }^{5}$ Department of Thoracic and Cardiovascular Surgery, Seoul National University Children's Hospital, \\ Seoul National University College of Medicine, Seoul, South Korea
}

\begin{abstract}
The need for appropriate technology in global health has expanded dramatically as the gap between industrialized and developing countries continues to expand. However, there is no collective knowledge of appropriate technology in global health. Thus, this study intends to provide light on the latest developments in the field of appropriate technology in global health and to speculate on future directions. A rapid review, or simplified technique, was used to systematically identify and summarize emerging papers. The search technique used the keywords "global health" and "appropriate technology." The total number of papers collected from PubMed and Scopus was 427, and 19 articles were thoroughly reviewed for the result section following the research. The study's conclusions included the following: 1) an assessment of appropriate technology adopted in developing countries; and 2) strategies for implementing appropriate technologies in global health. Additionally, we drew lessons and identified problems to serve as a useful guide for future research and development in appropriate technology. This review uncovered a small but valuable level of information about acceptable technology in global health.
\end{abstract}

KEYWORDS: global health, appropriate technology, rapid review, developing countries

\section{Introduction}

Appropriate technology is defined as any object, idea, process, or practice that fulfills human needs under consideration of the community's political, cultural, environmental, and economic conditions. Economist Dr. Ernest Friedrich Schumacher, who first coined the term "appropriate technology," argued that appropriate technology must be small scaled, locally controlled, inexpensive, ecologically sound, energy efficient, labor-intensive, and compatible with human needs (Schumacher n.d.). Such features of appropriate technology make appropriate technology a good foundational tool for less developed countries to fulfill the basic needs of their people who have been largely left out from the modern industrial process.

\footnotetext{
${ }^{\dagger}$ To whom correspondence should be addressed.

E-mail: joheo@nafi.re.kr/woonghan@snu.ac.kr

Receiced: 30 September 2021, Revised: 9 November 2021,

Accepted: 15 November 2021
}

The need of appropriate technology in global health has significantly increased following the ever-growing gap in economic development between developed and developing countries. The economic gap has been a major limiting factor in transferring developed countries' health related services and technology to developing countries. As a result, appropriate technology has played an effective mechanism that transformed modern technology into what can be most ideally accepted by those who use it.

The WHO Basic Radiology System (BRS) in 1975 is an example of appropriate technology in global health. BRS is a "simplified version of a standard radiographic unit" that can perform routine radiographic examinations in regions deprived of radio diagnostic service for economic and geographic reasons (World Health Organization 1994). The WHO BRS demonstrated high quality images and administrative advantages including safety, energy efficiency, and ease of use. By 1991 the WHO BRS was known to report the highest number of 
radiographs awarded and met the common needs of the majority in cases such as fracture, pregnancy, chest diseases, parasites, and abdominal pain (ibid).

Current uses of appropriate technology in global health are countless. Appropriate technology is used in laboratory medicine technology, allowing rapid and easy-to-access diagnostic tests to infectious diseases such as tuberculosis, HIV, hepatitis B and hepatitis C. Its use is also found in gene technology, starting from early detection and prevention of infectious disease and hereditary diseases to application in food production. It also enhanced the delivery system of pharmaceuticals and is widely used in environmental health to clean wastewater and develop safe housing designs.

However, appropriate technology still lays concerns before it gaps knowledge and application. Common limitations of application of appropriate technology include lack of access to databases or other sources of information, lack of funding, lack of commitment and political support, weak national health care system, poorly equipped hospitals, and lack of national expertise. As such, it is critical for global and national health institutions to collaborate with local organizations and donor agencies to ensure that they accurately review limitations of existing systems and develop more rational mechanisms that are effective according to the community's needs and priorities. By categorizing and summarizing the evidence, this rapid review aimed to provide a present status of existing research of appropriate technology in global health.

\section{Method}

Rapid review is a form of systematic review in which current studies are carefully examined to see if they match the researcher's point of view or a specific research issue. In this regard, rapid review is useful for knowledge synthesis. We conducted a rapid review based on the Preferred Reporting Items for Systematic Reviews and Meta-Analysis (PRISMA) checklist in order to examine the current status and application cases of health-related appropriate technologies globally and to present the factors that influence the introduction of such appropriate technologies.

\section{Eligibility criteria}

Appropriate Technology is described as "any object, idea, process, or practice that fulfills human needs while taking into account the community's political, cultural, environmental, and economic conditions," as previously said. The medical system or systemic improvement can also be offered as a form of healthrelated appropriate technology. In light of the current pandemic crisis and the broad availability of mobile devices, it presents the possibility of expanding appropriate technology offered in a non-face-to-face public approach as a means of medical system development. This paper developed the following screening criteria based on this viewpoint on appropriate technology. Records are widely collected through PubMed and Scopus using the phrases "global health" AND "appropriate technology" and verified for eligibility through the following steps:

1. A record is excluded and categorized as 'Content beyond scope' if it merely provides a simple technical introduction, animal-related intervention, or consequence that is assessed to be unrelated to health.

2. If a record isn't regarded an original article, such as a review or commentary, we opted to remove it and label it as "Not original study."

Papers that presented criteria in the process of introducing appropriate technology were also included as a result of researcher discussion.

\section{Study selection}

The following process was used to choose the studies. A total of 427 papers were uploaded in the Rayyan system (http:/ /rayyan.qcri.org), a free web-based research tool for systematic review. Then it was uploaded to the Mendeley program for review. 194 papers were deleted from the screening process because they were duplicates. The first round of screening was done using abstract analysis, and 168 items were eliminated. A secondary screening was carried out for more thorough verification. 23 records were identified as having content that was outside the scope of the project and were removed. A total of 23 entries were categorized as a non-original study, displaying Review or Commentary characteristics. In total, 42 papers were rejected based on the aforementioned criteria. The remaining 19 records were chosen as research articles, and mutual verification was carried out through talks among scholars.

\section{Results}

\section{Characteristics of the selected studies}

The features of the 19 studies considered in the review are 
Table 1. Characteristics of included studies $(n=19)$

\begin{tabular}{|c|c|c|c|c|c|}
\hline $\begin{array}{l}\text { First Author, } \\
\text { Year }\end{array}$ & $\begin{array}{l}\text { Research } \\
\text { study design }\end{array}$ & $\begin{array}{l}\text { Research } \\
\text { location }\end{array}$ & Research sample & Research objective & Outcome measures \\
\hline $\begin{array}{l}\text { Morse et al., } \\
2020\end{array}$ & $\begin{array}{l}\text { Transdisciplin } \\
\text { ary research } \\
\text { and formative } \\
\text { research }\end{array}$ & Malawi & $\begin{array}{l}\text { 1) shared dialogue } \\
\text { workshops }(\mathrm{n}=5), 2) \\
\text { sociospatial survey }(\mathrm{n}=777), \\
\text { 3) water point mapping and } \\
\text { testing }(\mathrm{n}=46) \text {, and 4) risks, } \\
\text { attitudes, norms, abilities, } \\
\text { and self-regulation (RANAS) } \\
\text { survey }(\mathrm{n}=100)\end{array}$ & $\begin{array}{l}\text { Aims to address the needs of the target population; } \\
\text { Introduced an HWTS that can be successfully taken up } \\
\text { and rolled out, the present study took into consideration } \\
\text { the opinions of the householders, the socioeconomics of } \\
\text { the households as the context of the design, } \\
\text { opportunities for local and cost-effective manufacture, } \\
\text { and the need for complementary and appropriate } \\
\text { educational tools; Encompassed facets of technology, } \\
\text { social context, and psychosocial factors using the De } \\
\text { Buck et al. (2018) theory of change as a framework. }\end{array}$ & $\begin{array}{l}\text { 1. Demographics } 2 \text {. Household water management and } \\
\text { gender-related issues } 3 \text {. Water-related social capital and } \\
\text { conflicts } 4 \text {. Water point mapping and water quality tests } \\
\text { 5. Behavioral factors influencing water treatment6. } \\
\text { Community codesign } 7 \text {. Moving toward trial }\end{array}$ \\
\hline $\begin{array}{l}\text { Liang et al., } \\
2018\end{array}$ & $\begin{array}{l}\text { a cross- } \\
\text { sectional } \\
\text { study }\end{array}$ & Uganda & $\begin{array}{l}28 \text { users }(6 \text { doctors, } 3 \text { clinical } \\
\text { officers, } 6 \text { nurses, } 4 \text { other } \\
\text { health professionals, } 6 \\
\text { administrative staff, and } 3 \\
\text { support staff) }\end{array}$ & $\begin{array}{l}\text { Describes the key opportunities and challenges in EHR } \\
\text { development in sub-Saharan Africa and to summarize } \\
\text { the development and implementation of a "Made-for- } \\
\text { Africa" EHR, Stre@mline, and how it has led to } \\
\text { improved care for over } 60,000 \text { vulnerable patients in a } \\
\text { rural region of Southwestern Uganda. }\end{array}$ & 1. system usability 2 . performance \\
\hline $\begin{array}{l}\text { Jeronimo et } \\
\text { al., } 2014\end{array}$ & clinical trial & $\begin{array}{l}\text { 1) India } \\
\text { 2) Nicaragua } \\
\text { 3) Uganda. }\end{array}$ & $\begin{array}{l}\text { 16,951 women } \\
\text { - Rural Uttar Pradesh: } \\
4,658 \\
\text { - Hyderabad: } 3,562 \\
\text { - Nicaragua: } 4,645 \\
\text { - Uganda: } 3,146\end{array}$ & $\begin{array}{l}\text { Evaluates the feasibility and performance of careHPV, a } \\
\text { novel hu- man papillomavirus (HPV) DNA test, when } \\
\text { used for screening women for cervical cancer in low- } \\
\text { resource settings }\end{array}$ & $\begin{array}{l}4 \text { screening tests: } \\
\text { 1) a self-collected vaginal sample for careHPV testing } \\
\text { 2) a pelvic examination using a speculum during which } \\
\text { additional cervical samples were taken for careHPV } \\
\text { and conventional Papanicolaou test } \\
\text { 3) careHPV specimen for both vaginal and cervical } \\
\text { samples } \\
\text { 4) Visual inspection with acetic acid L5 }\end{array}$ \\
\hline Sesan, 2012 & $\begin{array}{l}\text { qualitative } \\
\text { study }\end{array}$ & Kenya & 24 non-elite and elite & $\begin{array}{l}\text { Highlights the implications of the findings presented } \\
\text { here for energy poverty alleviation and improved stove } \\
\text { development policy }\end{array}$ & $\begin{array}{l}\text { 1. Description and cost of smoke alleviation } \\
\text { interventions promoted by Practical Action in selected } \\
\text { research site 2. Socio-cultural realities influence } \\
\text { household priorities } 3 \text {. Economic realities determine } \\
\text { household priorities } 4 \text {. The United States } \\
\text { Environmental Protection Agency (USEPA) smoke } \\
\text { alleviation project: targets, strategies, outcomes }\end{array}$ \\
\hline $\begin{array}{l}\text { Parham et al., } \\
2010\end{array}$ & case study & Zambia & $\mathrm{n} / \mathrm{a}$ & $\begin{array}{l}\text { Present a system operated by nonphysician health } \\
\text { providers that used widely available and affordable } \\
\text { communication technology to create locally adaptable } \\
\text { and sustainable public sector cervical cancer prevention } \\
\text { program in Zambia }\end{array}$ & $\begin{array}{l}\text { 1. Trained nurses to perform visual inspection with } \\
\text { acetic acid aided by digital cervicography using } \\
\text { predefined criteria } 2 \text {. Materials required for digital } \\
\text { cervicography } 3 \text {. Reviewed electronic digital images } \\
\text { 4. Same-visit cryotherapy or referral for further } \\
\text { evaluation by a gynecologist }\end{array}$ \\
\hline
\end{tabular}




\begin{tabular}{|c|c|c|c|c|c|}
\hline $\begin{array}{l}\text { First Author, } \\
\text { Year }\end{array}$ & $\begin{array}{l}\text { Research } \\
\text { study design }\end{array}$ & $\begin{array}{l}\text { Research } \\
\text { location }\end{array}$ & Research sample & Research objective & Outcome measures \\
\hline $\begin{array}{l}\text { Dunmade et } \\
\text { al., } 2002\end{array}$ & $\begin{array}{l}\text { narrative } \\
\text { study }\end{array}$ & Nigeria & $\mathrm{n} / \mathrm{a}$ & $\begin{array}{l}\text { Identifies indicators that will help assess the } \\
\text { sustainability of these foreign technologies-indicators } \\
\text { that will inform and guide all stakeholders as they make } \\
\text { decisions regarding the acceptability of all such } \\
\text { technology in the nation }\end{array}$ & $\begin{array}{l}\text { 1. Previous considerations of sustainability } 2 \text {. Primary } \\
\text { indicators of foreign technology sustainability } 3 \text {. } \\
\text { Secondary indicators of foreign technology } \\
\text { sustainability }\end{array}$ \\
\hline $\begin{array}{l}\text { Labbé et al., } \\
2001\end{array}$ & $\begin{array}{l}\text { clinical trial } \\
\text { study }\end{array}$ & $\begin{array}{l}\text { The Lao } \\
\text { People's } \\
\text { Democratic } \\
\text { Republic }\end{array}$ & $\begin{array}{l}194 \text { blood sample of } \\
\text { individuals with fever or a } \\
\text { history of fever }\end{array}$ & $\begin{array}{l}\text { Evaluates the performance of one simple, rapid and } \\
\text { inexpensive diagnostic assay when used by trained local } \\
\text { healthcare providers in a rural field setting in Laos }\end{array}$ & 1. sensitivity 2. specificity \\
\hline $\begin{array}{l}\text { Mulokozi et } \\
\text { al., } 2001\end{array}$ & $\begin{array}{l}\text { clinical trial } \\
\text { study }\end{array}$ & Tanzania & $\begin{array}{l}\text { Preintervention: } \\
250 \text { (intervention) } \\
150 \text { (control) } \\
\text { Postintervention: } \\
239 \text { (intervention) } \\
126 \text { (control) } \\
4 \% \text { and } 16 \% \text { loss to follow- } \\
\text { up) }\end{array}$ & $\begin{array}{l}\text { Explores three ways to increase the dryers' nutritional } \\
\text { impact. } \\
\text { 1) designing models that responded to women's needs, } \\
\text { more dryers might be constructed, increasing the } \\
\text { production of dried foods. } \\
\text { 2) developing an education strategy that ensured that all } \\
\text { community members received the same basic } \\
\text { information, families might adopt the dryers and feed } \\
\text { the nutritionally rich dried food products to their 12- to } \\
\text { 71-month-old children. } \\
\text { 3) providing women with additional nutritional } \\
\text { information and skill training might make them feel } \\
\text { more empowered to access the resources they needed to } \\
\text { adopt the improved technology. }\end{array}$ & $\begin{array}{l}\text { 1. Women's knowledge of solar drying } 2 \text {. Percentage of } \\
\text { Production of dried foods } 3 \text {. The amount of } \beta \text {-carotene } \\
\text { in vegetables blanched } 4 \text {. Helen Keller International } \\
\text { (HKI) food-frequency method }\end{array}$ \\
\hline $\begin{array}{l}\text { Khodadadeh } \\
\text { et al., } 2001\end{array}$ & $\begin{array}{l}\text { randomized } \\
\text { controlled } \\
\text { trial }\end{array}$ & Iran & $\begin{array}{l}45 \text { in the prototype }(\mathrm{n}=25) \\
\text { in the electrical incubator } \\
(\mathrm{n}=20)\end{array}$ & $\begin{array}{l}\text { The main aim of the present study was to assess the } \\
\text { technical feasibility, efficiency and safety of the } \\
\text { prototype by comparing it with an air-heated electrical } \\
\text { incubator in routine use in the hospitals. }\end{array}$ & $\begin{array}{l}\text { 1. rectal and abdominal skin temperature, heart rate, } \\
\text { oxygen } 2 \text {. saturation and respiratory rate } 3 \text {. The } \\
\text { temperature, oxygen and humidity level of the canopy } \\
\text { and the room temperature }\end{array}$ \\
\hline $\begin{array}{l}\text { Parashari et } \\
\text { al., } 2000\end{array}$ & $\begin{array}{l}\text { clinical trial } \\
\text { study }\end{array}$ & India & $\mid \begin{array}{l}403 \text { women attending a } \\
\text { maternal and child health } \\
\text { care clinic who had abnormal } \\
\text { vaginal discharge and related } \\
\text { symptoms }\end{array}$ & $\begin{array}{l}\text { To improve the sensitivity of visual inspection and } \\
\text { reduce the numbers of non-specific results as much as } \\
\text { possible }\end{array}$ & $\begin{array}{l}\text { comparison with those obtained using colposcopy and/ } \\
\text { or histology }\end{array}$ \\
\hline $\begin{array}{l}\text { Nelson et al., } \\
1999\end{array}$ & $\begin{array}{l}\text { clinical trial } \\
\text { study }\end{array}$ & $\begin{array}{l}\text { Indonesian } \\
\text { island of } \\
\text { Lombok }\end{array}$ & $\begin{array}{l}385 \text { soloshat, } \\
433 \text { disposables }\end{array}$ & $\begin{array}{l}\text { Investigates the appropriateness of SoloShot in the } \\
\text { Indonesian campaign, compared to a standard dis- } \\
\text { posable syringe, in terms of vaccine wastage, dose } \\
\text { accuracy, and user acceptability }\end{array}$ & 1. accuracy 2. dose efficiency \\
\hline $\begin{array}{l}\text { Leggat et al., } \\
1997\end{array}$ & case study & $\mathrm{n} / \mathrm{a}$ & $\mathrm{n} / \mathrm{a}$ & $\begin{array}{l}\text { Examines the need for and the approach of the WHO } \\
\text { in developing and introducing the BRS, and the } \\
\text { developments after the introduction of the WHO-BRS, } \\
\text { which target ultrasound equipment. }\end{array}$ & $\begin{array}{l}\text { 1. the need for diagnostic imaging equipment } \\
\text { 2. appropriate technology for better health } \\
\text { 3. the WHO basic radiological system } \\
\text { 4. the next step: ultrasound }\end{array}$ \\
\hline
\end{tabular}


Table 1. Continued

\begin{tabular}{|c|c|c|c|c|c|}
\hline $\begin{array}{l}\text { First Author, } \\
\text { Year }\end{array}$ & $\begin{array}{l}\text { Research } \\
\text { study design }\end{array}$ & $\begin{array}{l}\text { Research } \\
\text { location }\end{array}$ & Research sample & Research objective & Outcome measures \\
\hline Free, 1992 & $\begin{array}{l}\text { narrative } \\
\text { study }\end{array}$ & $\mathrm{n} / \mathrm{a}$ & $\mathrm{n} / \mathrm{a}$ & $\begin{array}{l}\text { Overviews several strategies and mechanisms that have } \\
\text { been employed by the Program for Appropriate } \\
\text { Technology in Health over the past decade to address } \\
\text { the unmet needs for health technologies in the } \\
\text { developing world }\end{array}$ & $\begin{array}{l}\text { 1. public/private partnerships in the development of } \\
\text { priority technologies for health } 2 \text {. an overview of } \\
\text { mechanisms by which the public sector can address } \\
\text { health technology needs } 3 \text {. collaboration to develop a } \\
\text { consensus of need and a strategy for development } \\
\text { 4. Identification of a technology to meet the need } 5 \text {. } \\
\text { Identification of manufacturing partners } 5 \text {. Incentives } \\
\text { for commercial involvement in social technologies } \\
6 \text {. protecting the public sector's interests } 7 \text {. The role of } \\
\text { bridging organizations in public/private partnerships }\end{array}$ \\
\hline Ong, 1991 & $\begin{array}{l}\text { narrative } \\
\text { study }\end{array}$ & $\mathrm{n} / \mathrm{a}$ & $\mathrm{n} / \mathrm{a}$ & $\begin{array}{l}\text { Discusses some of the problems faced by developing } \\
\text { countries in technology transfer }\end{array}$ & $\begin{array}{l}\text { 1. Components of work factors in human-machine } \\
\text { relationships } 2 \text {. the role of the operator } 3 \text {. Matching } \\
\text { technology with users } 4 \text {. Workplace characteristics and } \\
\text { working environment } 5 \text {. Human resources and } \\
\text { economic factors }\end{array}$ \\
\hline $\begin{array}{l}\text { Ritenbaugh et } \\
\text { al., } 1989\end{array}$ & clinical trial & Egypt & $\begin{array}{l}343 \text { infants in developing } \\
\text { countries }\end{array}$ & $\begin{array}{l}\text { Determines whether a system could be developed which } \\
\text { would provide adequate epidemiologic data on } \\
\text { pregnancy and birth outcome to serve as part of a } \\
\text { monitoring system; detail the methods used to address } \\
\text { the above questions and to partially test the proposed } \\
\text { system }\end{array}$ & 1. weight of babies 2 . sensitivity 3 . specificity \\
\hline $\begin{array}{l}\text { Nabarro et al., } \\
1988\end{array}$ & clinical trial & $\begin{array}{l}\text { Developing } \\
\text { countries }\end{array}$ & $\begin{array}{l}\text { children in developing } \\
\text { countries }\end{array}$ & $\begin{array}{l}\text { Re-examines the importance of widespread growth } \\
\text { monitoring as a part of child care in developing } \\
\text { countries }\end{array}$ & 1. assessment of health and growth of child \\
\hline $\begin{array}{l}\text { Monk et al., } \\
1984\end{array}$ & $\begin{array}{l}\text { narrative } \\
\text { study }\end{array}$ & Bangladesh & Halda river water quality & $\begin{array}{l}\text { Designs a low-technology water treatment plant for } \\
\text { developing nations to fit local conditions }\end{array}$ & $\begin{array}{l}\text { 1. Beneficial and cost-effective results for the client in } \\
\text { a developing nation } 2 \text {. satisfaction of the design } \\
\text { engineer }\end{array}$ \\
\hline $\begin{array}{l}\text { Sanborn et al., } \\
1984\end{array}$ & clinical trial & $\begin{array}{l}\text { Mali and } \\
\text { Upper Volta }\end{array}$ & 50 specimens & $\begin{array}{l}\text { Describes preliminary field evaluations of a portable } \\
\text { coagglutination test kit for the rapid, specific bedside } \\
\text { diagnosis of meningitis patients }\end{array}$ & $\begin{array}{l}\text { Comparison of coagglutination test results on CSF } \\
\text { specimens for the diagnosis of meningitis which were } \\
\text { obtained by African medical attendants and verified by } \\
\text { an established microbiology laboratory }\end{array}$ \\
\hline $\begin{array}{l}\text { Feachem, } \\
1980\end{array}$ & $\begin{array}{l}\text { narrative } \\
\text { study }\end{array}$ & $\mathrm{n} / \mathrm{a}$ & $\mathrm{n} / \mathrm{a}$ & $\begin{array}{l}\text { Introduces a case appropriate technology and } \\
\text { community participation and explores negative view }\end{array}$ & $\begin{array}{l}\text { 1. concept of appropriate technology } 2 \text {. selecting } \\
\text { appropriate technology } \\
\text { 3. simplicity and maintenance } 4 \text {. a fashionable approach } \\
\text { 5. issues in community participation } 6 \text {. aims of } \\
\text { community participation }\end{array}$ \\
\hline
\end{tabular}


summarized in Table 1. The research location is one of the elements extracted. The research was conducted in low- and middle-income countries on the African and Asian continents. Nine research $(9 / 19,47.3 \%)$ have been completed in the African region (Dunmade, 2002; Liang et al., 2018; Morse et al., 2020; Mulokozi et al., 2001; Parham et al., 2010; Ritenbaugh et al., 1989; Sanborn and Toure, 1984; Sesan, 2012); and five studies $(5 / 19,26.3 \%)$ have been completed in the Asian region (Khodadadeh et al., 2001; Labbé et al., 2001; Monk, Hall, and Hussain, 1984; Nelson, Sutanto, and Suradana, 1999; Parashari et al., 2000). Another feature that has been retrieved is the research design. This review categorized the selected papers on appropriate technology and global health according to their research designs. The research designs used in selected studies include narrative research (6/ 19, 31.6\%) (Dunmade, 2002; Feachem, 1980; Free, 1992; Monk, Hall, and Hussain, 1984; Nabarro and Chinnock, 1988; Ong, 1991), clinical trial research $(6 / 19,31.6 \%)$ (Jeronimo et al., 2014; Labbé et al., 2001; Mulokozi et al., 2001; Nelson, Sutanto, and Suradana, 1999; Parashari et al., 2000; Ritenbaugh et al., 1989; Sanborn and Toure, 1984), case studies (2/ 19, 10.5\%) (Parham et al., 2010), randomized control trial research $(1 / 19,5.3 \%)$ (Khodadadeh et al., 2001), qualitative research $(1 / 19,5.3 \%)$ (Sesan, 2012), cross-sectional research (1/19, 5.3\%) (Liang et al., 2018), and transdisciplinary research $(1 / 19,5.3 \%)$ (Morse et al., 2020). Additionally, the selected studies' objectives and outcomes were obtained. The studies that were chosen to highlight the following outcomes: performance, usability, and needs. Ten studies illustrated the performance of appropriate technology launched there in research (10/19, 52.6) (Jeronimo et al., 2014; Khodadadeh et al., 2001; Labbé et al., 2001; Liang et al., 2018; Nabarro and Chinnock, 1988; Nelson, Sutanto, and Suradana, 1999; Parashari et al., 2000; Parham et al., 2010; Ritenbaugh et al., 1989; Sanborn and Toure, 1984; Sesan, 2012), four studies included usability as a research objective and measure (4/19, 21.1\%) (Dunmade, 2002; Monk, Hall, and Hussain, 1984; Morse et al., 2020; Ong, 1991), two studies joint performance and usability (2/ 19, 10.5\%) (Liang et al., 2018; Mulokozi et al., 2001), and two studies indicated the need for appropriate technology (2/ 19, 10.5\%) (Free, 1992; Leggat, 1997).

\section{Evaluation of appropriate technologies implemented in developing countries}

Fifteen studies examined appropriate technologies in developing countries, and we analyzed the evaluation results to identify the strengths, limitations, and recommendations for appropriate technology use. Table 2 summarizes the assessment for each study. These findings were mainly positive in their evaluation of appropriate technology use in low-resource settings. The majority of studies evaluated appropriate technologies as easy to use (Khodadadeh et al., 2001; Labbé et al., 2001; Mulokozi et al., 2001; Nelson, Sutanto, and Suradana, 1999). Numerous studies have demonstrated the cost-effectiveness of appropriate technologies (Leggat, 1997; Parashari et al., 2000; Parham et al., 2010). According to certain research, appropriate technology can help decrease health risks by supplying drinkable water and reducing smoke generated during cooking (Morse et al., 2020; Sesan, 2012). Furthermore, studies have indicated a beneficial influence on women's productivity and efficiency (Mulokozi et al., 2001), improvements in patient assessment (Nabarro and Chinnock, 1988; Ritenbaugh et al., 1989), speed of use (Sanborn and Toure, 1984), and maximizing of local labor and resources (Monk, Hall, and Hussain, 1984).

This rapid review also explored limitations. Some studies mentioned a deficiency of necessary functions (Khodadadeh et al., 2001; Parham et al., 2010). Several studies also cited disputes amongst community residents, such as artisans demanding high fees for their services (Mulokozi et al., 2001), and competition between traditional birth attendants and nurses over the use of appropriate technology (Ritenbaugh et al., 1989). Certain research indicated low community participation in implementing appropriate technologies as their limitation (Morse et al., 2020; Nabarro and Chinnock, 1988). As per with one study, their constraint is the inability to discard huge disposables of appropriate technology (Nelson, Sutanto, and Suradana, 1999), while another study discovered a lack of data portability between hospitals (Liang et al., 2018). Furthermore, one study noted that appropriate technology was difficult to learn at first use (Sesan, 2012).

Notable recommendations include the use of community leadership (Morse et al., 2020), user training (Jeronimo et al., 2014; Liang et al., 2018), sequential piloting of appropriate technology (Liang et al., 2018), an evaluation method at each stage of implementation (Parham et al., 2010; Sesan, 2012), and additional appropriate technology that would enhance the integration of existing technology (Leggat, 1997; Parashari et al., 2000). 
Table 2. Characteristics of Appropriate Technologies in the Selected Studies $(n=15)$

\begin{tabular}{|c|c|c|c|c|c|}
\hline Category & Appropriate technology & Product details & User & Evaluation & Recommendations \\
\hline technology & $\begin{array}{l}\text { Solar disinfection } \\
\text { (SODIS) system } \\
\text { Developed by Helvetas } \\
\text { Swiss Intercooperation } \\
\text { and the ETH-Water } \\
\text { Research Institute } \\
\text { Eawag } \\
\text { Morse } \text { et al., } 2020\end{array}$ & $\begin{array}{l}\text { water treatment at the } \\
\text { household level }\end{array}$ & $\begin{array}{l}\text { Community } \\
\text { residents }\end{array}$ & $\begin{array}{l}\text { Strength } \\
\text { 1. provide drinkable water which fits to the WHO water } \\
\text { standards } \\
\text { Limitations } \\
\text { 1. gender issue 2. low community participation }\end{array}$ & $\begin{array}{l}\text { 1. the use of community leadership } \\
\text { (traditional, religious, government } \\
\text { workers, etc.) and volunteers as change } \\
\text { agents who will be in place for the long } \\
\text { term and can integrate the promotion of } \\
\text { the SODIS system with other water, } \\
\text { sanitation, and hygiene interventions } 2 . \\
\text { must be cognizant of both male and } \\
\text { female perceptions and financial } \\
\text { priorities }\end{array}$ \\
\hline $\begin{array}{l}\text { health } \\
\text { technology- } \\
\text { digital }\end{array}$ & $\begin{array}{l}\text { Stre@mline platform } \\
\text { (EHR system) } \\
\text { Developed by Ugandan } \\
\text { software developers } \\
\text { (istreams) and a team } \\
\text { of physicians from the } \\
\text { Kisiizi Hospital } \\
\text { (private not-for-profit } \\
\text { hospital in } \\
\text { Southwestern Uganda) } \\
\text { Liang et al., } 2018\end{array}$ & $\begin{array}{l}\text { providing an ideal context for } \\
\text { the development of a system } \\
\text { ideal for rural and remote } \\
\text { health facilities in sub-Saharan } \\
\text { Africa. }\end{array}$ & $\begin{array}{l}\text { healthcare } \\
\text { workers }\end{array}$ & $\begin{array}{l}\text { Strengths } \\
\text { 1. well-designed, sustainable and scalable technological } \\
\text { solutions for local settings } 2 \text {. effective local support for } \\
\text { maintenance and further development through an intimate } \\
\text { understanding of local needs } 3 \text {. economically sustainable, } \\
\text { with less external donor funding needed } 4 \text {. local pride can be } \\
\text { an important contributor to the adoption of any technology } \\
\text { and well leveraged in the development and application of } \\
\text { Stre@mline } 5 \text {. strong leadership from clinician-administrators } \\
\text { Limitations } \\
\text { 1. lack of data portability between different hospitals } 2 . \text { cost } \\
\text { prohibitive for small public hospitals and clinics within } \\
\text { Uganda and other African countries }\end{array}$ & $\begin{array}{l}\text { 1. ensure and mandate computer } \\
\text { workshops for all hospital employees } \\
\text { 2. organize piloting the EHR } \\
\text { sequentially, one department at a time, } \\
\text { until it was scaled across each } \\
\text { department }\end{array}$ \\
\hline $\begin{array}{l}\text { health } \\
\text { technology }\end{array}$ & $\begin{array}{l}\text { careHPV Test Kit } \\
\text { Developed by } \\
\text { QIAGEN, } \\
\text { Gaithersburg, MD } \\
\text { Jeronimo et al., } 2014\end{array}$ & $\begin{array}{l}\text { a simplified, robust, and } \\
\text { affordable HPV test that could } \\
\text { be used in low-resource } \\
\text { settings under a wider range of } \\
\text { ambient conditions }\end{array}$ & women & $\begin{array}{l}\text { Strengths } \\
\text { 1. can be run in any room because it does not need running } \\
\text { water or air conditioning } 2 \text {. the process is simple and can be } \\
\text { completed by people with limited laboratory training } 3 \text {. does } \\
\text { not require pelvic evaluation } \\
\text { Limitations } \\
\text { 1. may overestimate the clinical sensitivity of the tests } \\
\text { evaluated and the results }\end{array}$ & $\begin{array}{l}\text { 1. the performance of local expert should } \\
\text { be adequate }\end{array}$ \\
\hline technology & $\begin{array}{l}\text { Improved cooking } \\
\text { stove (various } \\
\text { prototype exists) } \\
\text { Sesan, T., } 2012\end{array}$ & $\begin{array}{l}\text { to burn biomass more } \\
\text { efficiently and hence uses less } \\
\text { fuel, or emits less smoke, than } \\
\text { traditional cooking devices }\end{array}$ & $\begin{array}{l}\text { Community } \\
\text { residents }\end{array}$ & $\begin{array}{l}\text { Strengths } \\
\text { mitigation of smoke-related health problems, reduction of } \\
\text { human and financial capital spent in obtaining biomass fuels, } \\
\text { reduced pressure on forest resources; and reduced greenhouse } \\
\text { gas emissions } \\
\text { Limitations } \\
\text { many poor households find it difficult to pay for these 'low- } \\
\text { cost' interventions in the first instance/ some cookers (like the } \\
\text { solar cooker) requires young women because its difficult to } \\
\text { learn how to use it }\end{array}$ & $\begin{array}{l}\text { more measured steps which respond to } \\
\text { the socio-economic realities of poor } \\
\text { households are likely to engender more } \\
\text { appropriate solutions }\end{array}$ \\
\hline
\end{tabular}




\begin{tabular}{|c|c|c|c|c|c|}
\hline Category & Appropriate technology & Product details & User & Evaluation & Recommendations \\
\hline $\begin{array}{l}\text { health } \\
\text { technology- } \\
\text { digital }\end{array}$ & \begin{tabular}{|l|} 
electronic cervical \\
cancer control (eC3) \\
developed by Center \\
for Infectious Disease \\
Research in Zambia \\
Parham et al., 2010
\end{tabular} & $\begin{array}{l}\text { a system operated by } \\
\text { nonphysician health providers } \\
\text { that used widely available and } \\
\text { affordable communication } \\
\text { technology to create locally } \\
\text { adaptable and sustainable } \\
\text { public sector cervical cancer } \\
\text { prevention program in Zambia }\end{array}$ & nurses & $\begin{array}{l}\text { Strengths } \\
\text { a low- cost and locally appropriate platform for the } \\
\text { integration of future HPV-based cervical cancer screening } \\
\text { protocols } \\
\text { Limitations } \\
\text { 1. photographs are two-dimensional } 2 \text {. the ability of } \\
\text { consultants to make appropriate decisions is limited } 3 \text {. if } \\
\text { cameras fail, need to be sent outside the country for repair } \\
\begin{array}{l}\text { 4. digital cervicography is only a screening test and, to be } \\
\text { effective }\end{array}\end{array}$ & $\begin{array}{l}\text { 1. must be incorporated within a system } \\
\text { where its results can be monitored, } \\
\text { evaluated, assessed by experts, and } \\
\text { linked with appropriate treatment when } \\
\text { necessary }\end{array}$ \\
\hline $\begin{array}{l}\text { health } \\
\text { technology }\end{array}$ & $\begin{array}{l}\text { dipstick assay } \\
\text { developed by the } \\
\text { Program for } \\
\text { Appropriate } \\
\text { Technology in Health } \\
\text { (PATH) } \\
\text { Labbé et al., } 2001 \\
\end{array}$ & $\begin{array}{l}\text { Detect true P. falciparum } \\
\text { infections reliably }\end{array}$ & $\begin{array}{l}\text { health care } \\
\text { worker }\end{array}$ & $\begin{array}{l}\text { Strengths } \\
\text { 1. the field health care workers were quickly taught how to } \\
\text { use and to interpret the results of the PATH assay } 2 \text {. rapid } \\
\text { Limitations } \\
\text { 1. specificities may have increased if PCR had been used as } \\
\text { the reference standard }\end{array}$ & $\left.\right|^{\mathrm{n} / \mathrm{a}}$ \\
\hline technology & $\begin{array}{l}\text { solar dryers developed } \\
\text { by Tanzania Food and } \\
\text { Nutrition Centre } \\
\text { (TFNC) and the } \\
\text { Ministry of Health and } \\
\text { the Ministries of } \\
\text { Agriculture and } \\
\text { Livestock Develop- } \\
\text { ment and Community } \\
\text { Development, Children } \\
\text { and Women's Affairs } \\
\text { Mulokozi et al., } 2001\end{array}$ & $\begin{array}{l}\text { Reduce the exposure of foods } \\
\text { to contaminants and direct sun, } \\
\text { the time needed for drying, and } \\
\text { the humidity levels of the foods } \\
\text { so that the dried foods could be } \\
\text { better stored; Increase women's } \\
\text { access to food-processing } \\
\text { technologies that extend the } \\
\text { avail- ability of vitamin A and } \\
\text { provitamin vitamin A-rich } \\
\text { foods, reduce nutrient losses } \\
\text { due to traditional processing } \\
\text { methods, and improve the } \\
\text { hygienic and nutritional quality } \\
\text { of the dried food products }\end{array}$ & women & $\begin{array}{l}\text { Strengths } \\
\text { 1. increased women's productivity and efficiency } \\
\text { 2. lighter in weight and portable } \\
\text { Limitations } \\
\text { 1. the artisans charged inflated prices for their services, which } \\
\text { might have discouraged community members from using } \\
\text { their service and limited the adoption rate } 2 \text {. adopters had } \\
\text { higher socioeconomic status than nonadopters, a consistently } \\
\text { reported pattern in technology development literature }\end{array}$ & $\begin{array}{l}\text { 1. Continue to promote the technology } 2 . \\
\text { Continue to promote production of fresh } \\
\text { fruits and vegetables } 3 \text {. Undertake a } \\
\text { longitudinal study to determine if dietary } \\
\text { consumption of vitamin A is sustained }\end{array}$ \\
\hline $\begin{array}{l}\text { health } \\
\text { technology }\end{array}$ & $\begin{array}{l}\text { non-electric transport } \\
\text { incubator developed by } \\
\text { Keele University, by } \\
\text { Yassaman Khodadadeh } \\
\text { in collaboration with } \\
\text { the Ministry of Health } \\
\text { of Iran } \\
\text { Khodadadeh et al., } \\
2001\end{array}$ & $\begin{array}{l}\text { The device produces heat via } \\
\text { an exothermic crystallisation } \\
\text { reaction initiated by a metal } \\
\text { disc, similar to that used by } \\
\text { commercially available hand } \\
\text { warmers. This system is } \\
\text { reusable. }\end{array}$ & nurses & $\begin{array}{l}\text { Strengths } \\
\text { 1. the new non-electric transport incubator is cheap, easy to } \\
\text { use, easy to maintain and repair } 2 \text {. confirmed its safety and } \\
\text { effectiveness in keeping non-distressed babies 3. transferring } \\
\text { babies from rural and isolated areas to bigger towns or cities, } \\
\text { between health facilities in a town or for indoor transport } \\
\text { between different units of a hospital. } \\
\text { Limitations } \\
\text { 1. has no humidity facility }\end{array}$ & $\mathrm{n} / \mathrm{a}$ \\
\hline $\begin{array}{l}\text { health } \\
\text { technology }\end{array}$ & $\begin{array}{l}\text { magnifying device } \\
\text { (Magnivisualizer) } \\
\text { developed by A.P. } \\
\text { Parashari } \text { et al., } 2000\end{array}$ & $\begin{array}{l}\text { for detecting precancerous } \\
\text { lesions of the uterine cervix }\end{array}$ & medical staff & $\begin{array}{l}\text { Strengths } \\
\text { 1. detecting most early cancerous and high-grade } \\
\text { precancerous lesions that have a high potential for } \\
\text { progression in low-resource settings 2. comparatively } \\
\text { inexpensive }\end{array}$ & $\begin{array}{l}\text { 1. additional requirement is an } \\
\text { examination table }\end{array}$ \\
\hline
\end{tabular}


Table 2. Continued

\begin{tabular}{|c|c|c|c|c|c|}
\hline Category & Appropriate technology & Product details & User & Evaluation & Recommendations \\
\hline $\begin{array}{l}\text { health } \\
\text { technology }\end{array}$ & \begin{tabular}{|l|} 
autodestruct syringe \\
developed by Program \\
for Appropriate \\
Technology in Health \\
(PATH) \\
Nelson et al., 1999 \\
\end{tabular} & $\begin{array}{l}\text { reduce the improper reuse of } \\
\text { syringes }\end{array}$ & vaccinator & $\begin{array}{l}\text { Strengths } \\
\text { 1. easier to use, faster, and more accurate than the disposable } \\
\text { syringe. } \\
\text { Limitations } \\
\text { 1. the syringe supply exceeded the disposal-box capacity, } \\
\text { resulting in over-filled boxes and protruding syringes }\end{array}$ & $\begin{array}{l}\text { 1. care must be taken to ensure } \\
\text { compliance with proper disposal } \\
\text { techniques }\end{array}$ \\
\hline $\begin{array}{l}\text { health } \\
\text { technology }\end{array}$ & $\begin{array}{l}\text { radiology, Basic } \\
\text { Radiological System } \\
\text { (BRS) developed by } \\
\text { WHO } \\
\text { Leggat et al., } 1997\end{array}$ & \begin{tabular}{|l|} 
the total package include \\
specifications for equipment and \\
battery powered generators to \\
overcome problems of unreliable \\
power supplies, and training \\
manuals for radiographic and \\
darkroom techniques and \\
radiograhic interpretation
\end{tabular} & $\begin{array}{l}\text { health care } \\
\text { workers }\end{array}$ & $\begin{array}{l}\text { Strengths } \\
\text { a universal standard can help produce specifications for cost- } \\
\text { effective radiological imaging systems that can be used in } \\
\text { rural areas }\end{array}$ & $\begin{array}{l}\text { purchase an appropriate general purpose } \\
\text { X-ray unit and then, as budgets permit, } \\
\text { a good general purpose ultrasound unit }\end{array}$ \\
\hline $\begin{array}{l}\text { health } \\
\text { technology }\end{array}$ & $\begin{array}{l}\text { birthweigh scale } \\
\text { developed by Program } \\
\text { for Appropriate } \\
\text { Technology in Health } \\
\text { (PATH) of Seattle, } \\
\text { Washington (USA) } \\
\text { Ritenbaugh } \text { et al., } 1989\end{array}$ & $\begin{array}{l}\text { to monitor birthweight in } \\
\text { developing countries, where } \\
\text { most infants are delivered at } \\
\text { home by traditional midwives, } \\
\text { could provide an important } \\
\text { component in the monitoring of } \\
\text { maternal and child health. }\end{array}$ & \begin{tabular}{|l|} 
traditional \\
practitioners, \\
mothers, and \\
other health \\
care \\
providers \\
\end{tabular} & $\begin{array}{l}\text { Strengths } \\
\text { 1. traditional birth attendants can be provided with the } \\
\text { information and tools to identify high-risk newborns and to } \\
\text { refer them for further care } 2 \text {. traditional birth attendants can } \\
\text { be provided with the information and tools to identify high- } \\
\text { risk newborns and to refer them for further care } \\
\text { Limitations } \\
\text { 1. reluctance of the dayas to participate or to report low- } \\
\text { weight babies: linked to competition between dayas and } \\
\text { nurses in communities in which nurses performed up to one- } \\
\text { third of deliveries }\end{array}$ & $\begin{array}{l}\text { 1. A data collection and management } \\
\text { network for reporting from the daya to } \\
\text { the health authorities should be tested } \\
\text { and the study should be expanded to } \\
\text { include other villages } 2 \text {. need to identify } \\
\text { risk factors and high risk areas to permit } \\
\text { targeted interventions aimed at } \\
\text { prevention }\end{array}$ \\
\hline $\begin{array}{l}\text { health } \\
\text { technology }\end{array}$ & $\begin{array}{l}\text { growth monitoring } \\
\text { developed by UNICEF } \\
\text { Nabarro et al., } 1988\end{array}$ & $\begin{array}{l}\text { To produce a sensitive indicator } \\
\text { in children's health by regularly } \\
\text { monitoring children's height } \\
\text { and weight }\end{array}$ & \begin{tabular}{|l|} 
traditional \\
practitioners, \\
mothers, and \\
other health \\
care \\
providers \\
\end{tabular} & $\begin{array}{l}\text { Strengths } \\
\text { 1. Can provide mothers knowledge and support that they } \\
\text { require in order to protect their children's growth 2. Can } \\
\text { provide doctors information in assessing health and growth } \\
\text { of children 3. Can give parents more power, making them } \\
\text { less dependent on doctors or clinics } \\
\text { Limitations } \\
\text { 1. Inadequate participation of international agencies 2. not } \\
\text { enough strategies developed for tackling children's nutritional } \\
\text { and health problems }\end{array}$ & $\begin{array}{l}\text { Need to answer following questions: } \\
\text { What are the risks associated with } \\
\text { growth faltering or weight loss? To what } \\
\text { extent can different health, educational or } \\
\text { welfare interventions reduce these risks? } \\
\text { How much will these interventions cost; } \\
\text { could the resources (including mothers' } \\
\text { time and enthusiasm) be put to better } \\
\text { use? }\end{array}$ \\
\hline technology & $\begin{array}{l}\text { Mohara Water } \\
\text { Treatment Plant } \\
\text { developed by Water } \\
\text { Supply and Sewerage } \\
\text { Authority (WASA) } \\
\text { Monk et al., } 1984\end{array}$ & $\begin{array}{l}\text { To provide prudent, cost- } \\
\text { effective water plant that could } \\
\text { be built and operated } \\
\text { practically and effectively } \\
\text { using native materials and } \\
\text { human resources }\end{array}$ & residents & $\begin{array}{l}\text { Strengths } \\
\text { 1. Produce reliable treatment, minimize imported items, } \\
\text { maximize local labor during construction and operation, limit } \\
\text { energy demands, use local materials whenever possible, and } \\
\text { provide adequate flexibility } \\
\text { Limitations } \\
\text { 1. To limit imported items and specify local materials where } \\
\text { possible }\end{array}$ & $\begin{array}{l}\text { 1. design facilities compatible with local } \\
\text { conditions } 2 \text {. maximize the use of local } \\
\text { materials and labor } 3 \text {. minimize the use } \\
\text { of local materials and labor } 4 \text {. minimize } \\
\text { dependence on overseas materials and } \\
\text { equipment } 5 \text {. education programs for } \\
\text { local professionals needed 5. research } \\
\text { and reevaluation is necessary }\end{array}$ \\
\hline
\end{tabular}


Table 3. Implementation Strategies for Appropriate Technologies $(n=4)$

\begin{tabular}{|c|c|}
\hline $\begin{array}{l}\text { First Author, } \\
\text { Year }\end{array}$ & Implementation strategies \\
\hline $\begin{array}{l}\text { Morse et al., } \\
2020\end{array}$ & $\begin{array}{l}\text { 1. Determining prototype and promotional approach: Assessment methods } \\
\text { 2. Factors influencing prototype development and implementation: Program environment factors, implementer related factors, } \\
\text { recipient related factors, contextual factors } \\
\text { 3. Promotional approaches: co-designed community SODIS prototype, messaging for technical use of treatment system, promoting } \\
\text { use through behavior change techniques } \\
\text { 4-1. Outputs and outcomes (short term): Evaluation of acceptability, adaption, dose, engagement, fidelity, reach, satisfaction, } \\
\text { recruitment, attrition } \\
\text { 4-2. Outputs and outcomes (medium term): behavior change } \\
\text { 4-3. Outputs and outcomes (long term): Reducing morbidity and mortality from diarrheal disease }\end{array}$ \\
\hline $\begin{array}{l}\text { Dunmade et al., } \\
2002\end{array}$ & $\begin{array}{l}\text { 1. Primary indicator: Adoptability } \\
\text { 2. Secondary indicator: 1) technical sustainability ((1) the accessibility of component parts, (2) the availability of the needed } \\
\text { infrastructure, (3) the availability of technical know-how to accomplish such service (4) the elapsed time between repairs), 2) } \\
\text { environmental sustainability ((1) resource consumption, (2) environmental releases, (3) resource conservation, (4) environmental } \\
\text { compliance) 3) economic sustainability ((1) affordability, (2) reusability, and (3) local availability of required servicing resources) } \\
\text { 4) socio-political sustainability ((1) the level of awareness, (2) acceptability, (3) govern- mental policy and continuity, (4) the socio- } \\
\text { cultural influence) }\end{array}$ \\
\hline Ong, 1991 & $\begin{array}{l}\text { Components of work factors in human-machine relationships } \\
\text { 1. operator, 2. tool (biomechanical, physical), 3. workstation and environment (biomechanical, anthropometry, workplace design, } \\
\text { climate), 4. task (new technology, training, job satisfaction, management system, working hours, shift work) }\end{array}$ \\
\hline Free, 1992 & $\begin{array}{l}\text { 1. Design (identify technology), 2. Specifications (identify need), 3. Consensus (collaboration), 4. Product (Manufacture), 5. Demand } \\
\text { (promote), 6. Application (introduce) }\end{array}$ \\
\hline
\end{tabular}

\section{Implementation strategies for appropriate technologies in global health}

Table 3 shows the strategies for implementing appropriate technology in global health. The assessment method and factors influencing prototype development and implementation (program environment factors, implementer related factors, recipient related factors, contextual factors) (Morse et al., 2020), adoptability (Dunmade, 2002), design (identify technology), and specifications (identify need) (Free, 1992) are all evaluated as input indicators. Promotional approaches (codesigned community-based prototype, message for technical use of treatment system, promoting use through behavior modification strategies) and process indicators (Morse et al., 2020). Technical, environmental, economic, and socio-political sustainability were identified as essential indicators in the appropriate technology implementation strategies for output criteria (Dunmade, 2002). Ong additionally identified components of work factors in human-machine interactions as crucial implementation indicators (Ong, 1991).

\section{Conclusion}

Appropriate technology in global health is a crucial inter- vention enhancing health in developing countries. In this rapid review, we identified 19 studies to systematically organize the existing appropriate technologies, their evaluation results, and implementation strategies.

In general, research have demonstrated the development of appropriate technologies of use in the field of global health. Additionally, numerous appropriate technologies have been implemented throughout the last four decades and have remained mostly concentrated in a few countries. Most of the research has focused on the deployment and performance of distributed technology in low-resource contexts. According to the analyzed research, the intended users were primarily community residents and health care professionals. However, the examined studies do not include an assessment of longterm health outcomes and they are primarily concerned with short-term outcomes. Furthermore, several implementation strategy components were discovered that might be used to the evaluation criteria.

\section{Study Limitation}

Our study may be limited by publication bias. This study did not include non-peer-reviewed articles, such as grey literature or program reports, and articles written in language 
other than English.

\section{Critical components of implementing an appropriate} technology in the Global health arena

\section{1) Community participation}

Numerous studies in this rapid review have established the significant importance of engaging the community in the application of appropriate technology in low-resource situations. The Alma Ata Declaration of 1978, which established the community as a critical component of primary health care planning, organization, operation, and control, elevated community engagement to a new level (WHO, 1978). Community involvement has emerged as a global health aim in recent years, with the establishment of the new Sustainable Development Goals. Integrated, people-centered health care is crucial for reaching the SDGs' goal of universal health coverage, and accomplishing this goal requires participatory approaches
(Marston et al., 2016). Apart from enhancing the efficiency of health initiatives through community participation, it is argued that effectively involving communities improves social capital, leading to increased community empowerment and, eventually, improved health status and reduced health inequities (Morgan, 2001). In this manner, including the community while using appropriate technology to promote health in lowresource settings makes the technology more sustainable.

\section{2) Systems approach}

Our findings emphasize the importance of a systems approach to disseminating appropriate technology in global health as shown in Figure 1. Delivering health related appropriate technology in low-resource regions is highly complex, as it requires the convergence of multiple disciplines. Integrative systems-based methodologies such as systems approach are increasingly attracting attention for their ability to promote the
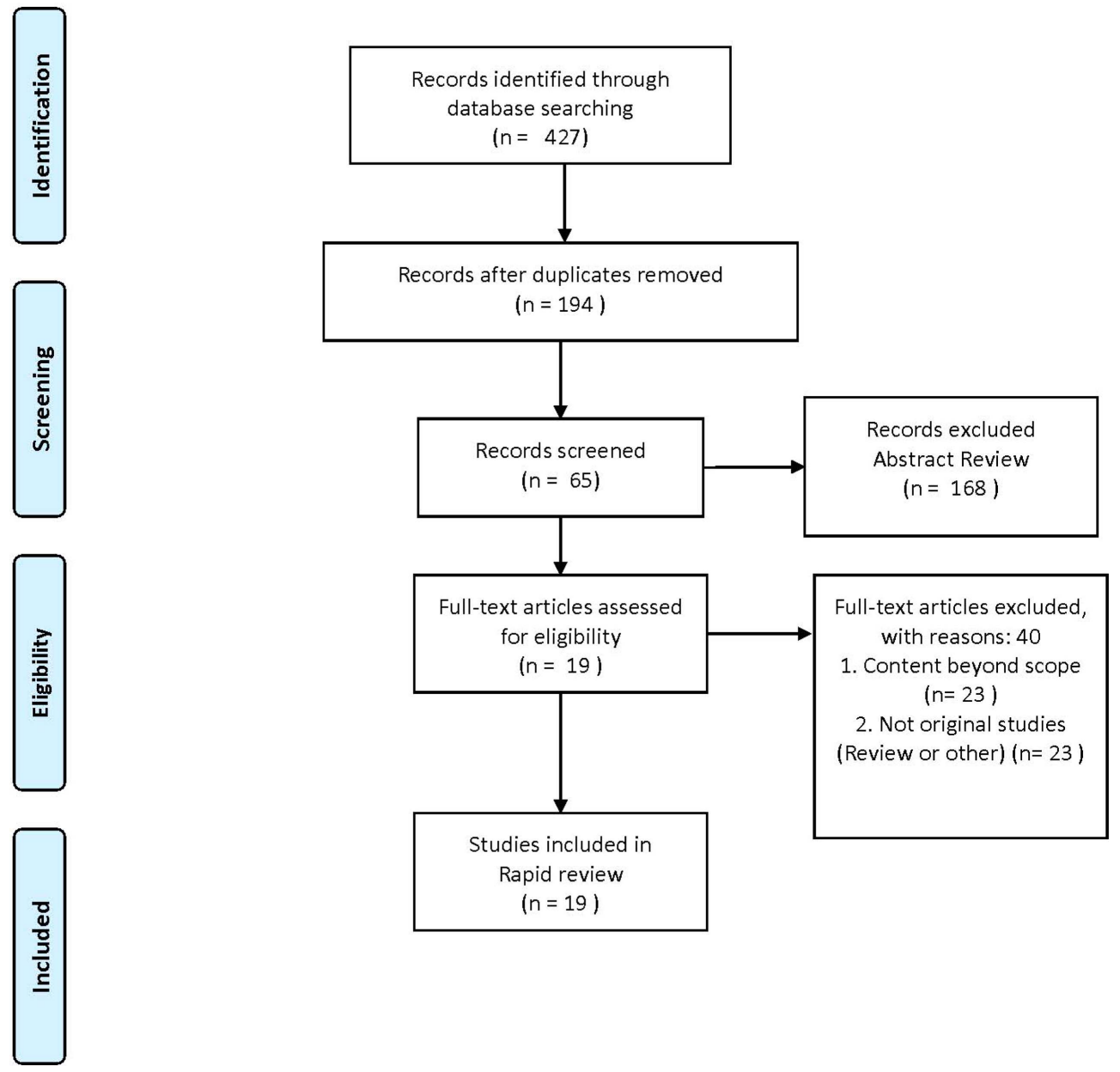

Figure 1. Flow chart of the literature search and screening process 
transdisciplinary collaboration (Mercure et al., 2015). One of main parts of systems approach is systems thinking which defined as "an integrated approach to grasping the dynamic linkages between complex economic, environmental, and social systems and assessing the potential consequences of change." (Fiksel et al., 2014) Systems thinking captures how to intervene to improve population's health. Systems thinking to selecting appropriate technology necessitates a scientific understanding of system complexity and an understanding for technology's role in health improvement. As a whole, our understanding of how to adopt appropriate technologies to improve health outcomes will be strengthened by a systems approach.

\section{3) Long term health outcome}

Several studies have mentioned short term health outcomes such as improvement of immediate health services, advancement of specificity and sensitivity, and performance of health care technologies (Jeronimo et al., 2014; Labbé et al., 2001; Liang et al., 2018). However, there is a dearth of information on the long-term health outcomes related with appropriate technology intervention. The professional developers must have a firm grasp on the effect that healthy interventions can have on one's prevailing and long-term health. Such studies are necessary to expand the range of possible health outcomes associated with clinical outcomes while including patient satisfaction as an endpoint.

\section{Future direction}

Various adaptable and low-marginal-cost digital interventions are being proposed as appropriate technologies these days. Digital technologies (apps, wearables, EHRs, and mHealth) have the potential to create a technology-enabled health system in which care exchanges occur outside of hospital settings and community individuals are encouraged to self-manage their health and illness (Greaves et al., 2019). Prior to developing and implementing digital health systems in low-resource settings, it is critical to determine whether an organization, institution, as well as a region or country is prepared to adopt new technology and processes. It is essential to understand the beneficial and negative perceptions of digital health systems among healthcare practitioners, engineers, patients, community residents, and program administrators. Therefore, measuring preparedness is one of the first elements in building a digital health plan for future direction.
Conflicts of Interest: The authors declare no conflicts of interest.

\section{References}

Dunmade, Israel. (2002). Indicators of Sustainability: Assessing the Suitability of a Foreign Technology for a Developing Economy. Technology in Society, 24(4), 461-471.

Feachem, R. G. (1980). Community Participation in Appropriate Water Supply and Sanitation Technologies: The Mythology for the Decade. Proceedings of the Royal Society of London Biological Sciences, 209(1174), 15-29. https://royalsocietypublishing.org/doi/abs/10.1098/rspb.1980.0068 (September 21, 2021).

Fiksel, Joseph et al. (2014). The Triple Value Model: A Systems Approach to Sustainable Solutions. Clean Technologies and Environmental Policy, 16(4), 691-702.

Free, Michael J. (1992). Addressing the Unmet Needs. International Journal of Technology Assessment in Health Care, 8(4), 623-634. http://lps3.www.cambridge.org.libproxy.snu.ac.kr/ core/journals/international-journal-of-technology-assessment-in-health-care/article/health-technologies-for-the-developing-world-addressing-the-unmet-needs/ 801DD59E8A926DD82A1A516FD23F3238 (September 21, 2021).

Greaves, F. et al. (2019). "What Is an Appropriate Level of Evidence for a Digital Health Intervention?" Lancet (London, England) 392(10165), 2665-67. https://pubmed.ncbi.nlm.nih.gov/ 30545779/ (September 30, 2021).

Jeronimo, Jose et al. (2014). "A Multicountry Evaluation of Care HPV Testing, Visual Inspection with Acetic Acid, and Papanicolaou Testing for the Detection of Cervical Cancer." International Journal of Gynecological Cancer, 24(3): 576-585.

Khodadadeh, Y., F. Nili, F. Nayeri, and Y. Wickramasinghe. (2001). Comparative Clinical Evaluation of a Prototype NonElectric Transport Incubator and an Electrical Infant Incubator in a Neonatal Unit. Medical and Biological Engineering and Computing, 39(5), 594-600. http://lps3.link.springer.com.libproxy.snu.ac.kr/article/10.1007/BF02345152 (September 21, 2021).

Labbé, A. C. et al. (2001). The Performance and Utility of Rapid Diagnostic Assays for Plasmodium Falciparum Malaria in a Field Setting in the Lao People's Democratic Republic. Annals of Tropical Medicine \& Parasitology, 95(7), 671-77. https://www.tandfonline.com/doi/abs/10.1080/ 00034983.2001.11813684 (September 21, 2021).

Leggat, P. A. 1997. Basic Radiological System: A Case Study in 
'Appropriate Technology for Better Health'. The Australian Journal of Rural Health, 5(2), 87-89. http://lps3.onlinelibrary.wiley.com.libproxy.snu.ac.kr/doi/full/10.1111/j.14401584.1997.tb00244.x (September 21, 2021).

Liang, Li et al. (2018). A Locally Developed Electronic Health Platform in Uganda: Development and Implementation of Stre@mline. JMIR Formative Research, 2(2), 1-6.

Marston, Cicely et al. (2016). Community Participation for Transformative Action on Women's, Children's and Adolescents' Health. Bulletin of the World Health Organization, 94(5), 376. /pmc/articles/PMC4857226/ (September 30, 2021).

Mercure, J.-F. et al. (2015). Modelling Complex Systems of Heterogeneous Agents to Better Design Sustainability Transitions Policy. Global Environmental Change, 37, 102-115. https:// arxiv.org/abs/1506.07432v4 (September 30, 2021).

Monk, Robert D.G., Terry Hall, and Mohammed Hussain. (1984). Real World Design: Appropriate Technology for Developing Nations. Journal / American Water Works Association, 76(6), 68-74. http://lps3.www.jstor.org.libproxy.snu.ac.kr/stable/ 41273149?seq=1\#metadata_info_tab_contents (September 21, 2021).

Morgan, L.M. (2001). Community Participation in Health: Perpetual Allure, Persistent Challenge. Health policy and planning 16(3), 221-230. https://pubmed.ncbi.nlm.nih.gov/ 11527862/ (September 30, 2021).

Morse, Tracy et al. (2020). A Transdisciplinary Methodology for Introducing Solar Water Disinfection to Rural Communities in Malawi-Formative Research Findings. Integrated Environmental Assessment and Management, 16(6), 871-884.

Mulokozi, G., L. Mselle, J. Mugyabuso, and C. Johnson-Welch. (2001). Reducing Subclinical Vitamin A Deficiency through Women's Adoption of Appropriate Technologies in Tanzania. Food and Nutrition Bulletin, 22(4), 400-407. https://journals.sagepub.com/doi/abs/10.1177/156482650102200410 (September 21, 2021).

Nabarro, David, and Paul Chinnock. (1988). Growth MonitoringInappropriate Promotion of an Appropriate Technology. Social Science and Medicine, 26(9), 941-948.
Nelson, C. M., A. Sutanto, and I. G.P. Suradana. (1999). Use of SoloShot Autodestruct Syringes Compared with Disposable Syringes, in a National Immunization Campaign in Indonesia. Bulletin of the World Health Organization, 77(1), 29-33.

Ong, Choon Nam. (1991). Ergonomics, Technology Transfer and Developing Countries. Ergonomics, 34(6), 799-814. http:// lps3.www.tandfonline.com.libproxy.snu.ac.kr/doi/abs/ 10.1080/00140139108967352 (September 21, 2021).

Parashari, A. et al. (2000). Low-Cost Technology for Screening Uterine Cervical Cancer. Bulletin of the World Health Organization, 78(8), 964-967. /pmc/articles/PMC2560819/ ?report=abstract (September 21, 2021).

Parham, Groesbeck P. et al. (2010). EC3-A Modern Telecommunications Matrix for Cervical Cancer Prevention in Zambia. Journal of Lower Genital Tract Disease, 14(3), 167-173.

Ritenbaugh, Cheryl K., Amin K. Said, Osman M. Galal, and Gail G. Harrison. (1989). Development and Evaluation of a ColourCoded Scale for Birthweight Surveillance in Rural Egypt. International Journal of Epidemiology 18(Supplement_2): S54-59. http://lps3.academic.oup.com.libproxy.snu.ac.kr/ije/ article/18/Supplement_2/S54/781253 (September 21, 2021).

Sanborn, W. R., and I. M. Toure. (1984). A Simple Kit System for Rapid Diagnosis of Cerebrospinal Meningitis in Rural Areas of Developing Countries. Bulletin of the World Health Organization, 62(2), 293-299. /pmc/articles/PMC2536302/ ?report=abstract (September 21, 2021).

Schumacher, E F. GOOD WORK.

Sesan, Temilade. (2012). Navigating the Limitations of Energy Poverty: Lessons from the Promotion of Improved Cooking Technologies in Kenya. Energy Policy, 47, 202-210.

WHO. (1978). Declaration of Alma-Ata in International Conference on Primary Health Care. World Health Organisation.

World Health Organization. (1994). Report from the Consultation Meeting on the WHO Basic Radiological Systems, Held at the WHO Collaborating Centre for General and Continuing Radiological Education, University Hospital, Lund, Sweden. World Health Organization. No. RAD/94. 